\title{
Selective Isolation and Identification of Arginine Degrading Bacteria; the Optimized Arginine Deaminase Production by Enterobacter sp. sgnl as a New Source of This Potentially Anti-Tumor Enzyme
}

\author{
Narjes Ebrahimi ${ }^{1}$, Sara Gharibi ${ }^{1}$, Mohammad Bagher Ghoshoon ${ }^{1}$, Zeinab Karimi ${ }^{1}$, Ahmad Gholami $^{1,2}$, Navid Nezafat ${ }^{2}$, \\ Milad Mohkam ${ }^{1}$, Younes Ghasemi ${ }^{1,2 *}$ \\ ${ }^{1}$ Department of Pharmaceutical Biotechnology, School of Pharmacy, Shiraz University of Medical Sciences, Shiraz, Iran. \\ ${ }^{2}$ Pharmaceutical Sciences Research Center, School of Pharmacy, Shiraz University of Medical Sciences, Shiraz, Iran.
}

\begin{tabular}{l} 
ARTICLE INFO \\
\hline Article history: \\
Received on: $19 / 04 / 2016$ \\
Revised on: 07/05/2016 \\
Accepted on: 09/06/2016 \\
Available online: $26 / 09 / 2016$ \\
\hline Key words: \\
Arginine deiminase, \\
Enterobacter sp. sgn1, \\
Arginine degrading enzymes, \\
Bacteria, Isolation.
\end{tabular}

\section{INTRODUCTION}

Some tumors require the extra cellular sources of some amino acids, which are considered as non-essential in normal cells, due to metabolic deficiencies (Stone et al., 2010; Kuo et $a l ., 2010)$. Thus, enzymatic degradation of these amino acids can be an effective strategy in the suppression of such tumors (Shen et al., 2006). Asparaginase is the example of amino acid depriving enzymes, which has been applied in the treatment of

\footnotetext{
* Corresponding Author

Younes Ghasemi, Department of Pharmaceutical Biotechnology,

School of Pharmacy, Shiraz University of Medical Sciences, Shiraz, Iran.

Emai:ghasemiy@sums.ac.ir
}

acute lymphoblastic leukemia for many years (Piatkowska-Jakubas et al., 2008). A similar approach might be exploited for arginine auxotrophic tumors (Feun et al., 2008). Arginine degrading enzymes consist of three main types of enzymes: arginine deiminase, arginase and arginine decarboxylase which exist in archaea, bacteria, and eukaria (Zúñiga et al., 2002; Knodler et al., 1998). To discover new sources for arginine degrading enzymes, one possible way is screening, isolation and characterization of the microorganisms. Among the arginine degrading enzymes, arginine deiminase (ADI) has been considered as an anti-tumor enzyme to treat hepatocellular carcinomas (HCCs) (Izzo et al., 2004, Ensor et al., 2002) and melanomas (Kuo et al., 2010, Feun and Savaraj, 2006) which are auxotrophic for arginine. 
The catabolism of arginine to citrulline and ammonia is catalyzed by this enzyme ( $\mathrm{Ni}$ et al., 2011) in the arginine deiminase pathway, which is utilized by a number of microorganisms such as Pseudomonas, Mycoplasma (Ni et al., 2009), Halobacterium (Monstadt and Holldorf, 1991), Lactobacillus (Arena et al., 1999), Lactococcus (Kim et al., 2007), and Streptococcus (Niven Jr et al., 1942) species) as an energy source (Ni et al., 2008, Mercenier et al., 1980). The aim of the present study was to isolate bacterial species, which are able to produce arginine degrading enzymes. For this purpose, a number of microorganisms were screened from various samples to obtain the species which can produce arginine degrading enzymes; using a convenient and sensitive screening procedure on phenol red indicator plates.

Furthermore, the enzyme activity was measured by Nessler's reagent, and the isolated species were characterized using 16S rRNA gene sequence analysis. Among the isolated species, Enterobacter sp. Sgn1, which has not been previously studied as a source of ADI, was selected for further research. Since the optimization of the enzyme production can result in achieving higher amounts of enzyme, the effect of temperature, $\mathrm{pH}$, the concentration of glucose and $\mathrm{Mg}^{+}$ion on the enzyme production was evaluated.

Minitab software was applied to design the experiments and citrulline was measured as the product of ADI activity. The ADI sequences of the isolated species were compared to the sequence of Mycoplasma arginini (the source of ADI enzyme, which is under investigation in clinical trials) to find the species with the similar sequences.

\section{MATERIALS AND METHODS}

\section{Materials and microorganisms}

L-Citrulline, diacetylmonoxime and thiosemicarbasiade were obtained from the Sigma Aldrich Company. Glucose, Larginine, $\mathrm{NaCl}, \mathrm{KH}_{2} \mathrm{PO}_{4}, \mathrm{MgCl}_{2}, \mathrm{MnCl}_{2}, \mathrm{FeSO}_{4}, \mathrm{CaCO}_{3}$, agar, sulfuric acid (95-98\%), phosphoric acid (85\%) and $\mathrm{FeCl}_{3}$ were purchased from the Merck Company. Phenol red was obtained from the Lobachemie Company, and the bacterial strains were isolated from various regions of Fars and Boushehr province.

\section{Screening of the arginine degrading bacteria using the plate method assay}

The test samples were collected from various regions of Fars and Boushehr province. Adding the sterile water to the soil samples, $1 \mathrm{~mL}$ of the diluted sediment samples was transferred to the selective screening medium (Ghasemi et al., 2008) and incubated for 24 hours at $37^{\circ} \mathrm{C}$.

The screening medium $(\mathrm{pH}=7)$ consisted of: $0.01 \%$ glucose, $1.5 \%$ L-arginine, $0.002 \% \mathrm{NaCl}, 0.075 \% \mathrm{KH}_{2} \mathrm{PO}_{4}, 0.05 \%$ $\mathrm{MgCl}_{2}, 0.01 \% \mathrm{MnCl}_{2}, 0.0005 \% \mathrm{FeSO}_{4}, 0.1 \mathrm{M} \mathrm{CaCO}_{3}, 1.7 \%$ agar and $0.005 \%$ phenol red, as the $\mathrm{pH}$ indicator. Colonies with the purple zone were considered as the arginine degrading species and were subsequently sub cultured for several times to get the pure colonies (colonies A-K).

\section{Activity determination of the arginine degrading enzymes}

The obtained pure colonies were subjected to further activity analysis of arginine degrading enzymes using Nessler's reagent to measure the ammonia concentration (Singh et al., 2013) as the product of arginine degrading enzymes. Arginine was used as the sole nitrogen source in the culture media. Cultured in $20 \mathrm{~mL}$ of the defined medium, the bacteria were incubated for 24 hours at $37^{\circ} \mathrm{C}$, after which $2 \mathrm{~mL}$ of each growth medium was collected and centrifuged to assess the concentration of ammonia in the supernatant. Then, $50 \mu \mathrm{L}$ of Nessler's reagent was added to $1 \mathrm{~mL}$ of the obtained supernatants, the concentration of the produced ammonia was quantified by measuring the absorbance at $480 \mathrm{~nm}$ (UV/Vis spectrometer, PG Instruments) (according to the standard curve of ammonium sulfate). The calculated values were correlated to the activity of arginine degrading enzymes within 24 hours of incubation (number of experiments=3).

\section{Identification of the isolated bacteria by sequence analysis of 16S rRNA gene}

Along with the morphological and biochemical characterization, molecular identification of the arginine degrading bacteria was carried out by $16 \mathrm{~S}$ rRNA sequence analysis, using the forward and reverse primers with the sequences of (5'CAGCCGCGGTAATAC-3') and (5'-ACGGGCGGTGTGTAC-3'), respectively. The $16 \mathrm{~S}$ rRNA gene was amplified using PCR amplification, under the following conditions: initial denaturation at $99^{\circ} \mathrm{C}$ for $5 \mathrm{~min}$; followed by 30 cycles of denaturation $\left(94^{\circ} \mathrm{C}\right.$ for $30 \mathrm{~s})$, annealing $\left(53-56^{\circ} \mathrm{C}\right.$ for $\left.30 \mathrm{~s}\right)$ and extension $\left(72^{\circ} \mathrm{C}\right.$ for $2: 30$ $\mathrm{s})$; the final extension was initiated at $72^{\circ} \mathrm{C}$ for $10 \mathrm{~min}$. The size of the resulted amplicon was confirmed by agarose gel electrophoresis and following gel purification (QIAquick gel extraction kit, Qiagen USA); furthermore, they were subjected to further sequence analysis (CinnaGen Co., Iran). The obtained sequences were compared with sequences deposited in GenBank database of National Center for Biotechnology Information (NCBI) by Basic Local Alignment Search Tool (BLAST).

\section{Optimization of the nutritional conditions for ADI enzyme production}

Among the isolated species, Enterobacter sp. sgnl, which was not previously studied for the ADI production, was selected for further studies. To optimize the ADI enzyme production, some culture parameters were evaluated via response surface methodology (RSM) (Kazemi et al., 2014) and BoxBehnken design (using Minitab software, version 16). These parameters were selected based on the reported parameters about other microorganisms: glucose concentration (Arena et al., 1999, Simon et al., 1982), $\mathrm{Mg}^{+}$concentration (Baur et al., 1989, Park et al., 1984), temperature (Kakimoto et al., 1971, Liu et al., 2008) and $\mathrm{pH}$ (Kakimoto et al., 1971, Park et al., 1984). 
Table 1: The Box-Behnken design for the four independent variables and the observed results for the designed experiments

\begin{tabular}{|c|c|c|c|c|c|c|}
\hline $\begin{array}{c}\text { Trial } \\
\text { number }\end{array}$ & $\begin{array}{c}\text { Temperature } \\
\left(\mathbf{X}_{1}\right) \\
\end{array}$ & $\begin{array}{c}\mathrm{pH} \\
\left(\mathbf{X}_{2}\right)\end{array}$ & $\begin{array}{c}\text { Glucose }(\%) \\
\left(\mathbf{X}_{3}\right) \\
\end{array}$ & $\begin{array}{c}\mathbf{M g}^{+}(\mathbf{M}) \\
\left(\mathbf{X}_{4}\right)\end{array}$ & $\begin{array}{c}\text { Observed amount of } \\
\text { citrulline }(\mu \mathrm{g} / \mathrm{mL})\end{array}$ & $\begin{array}{c}\text { Predicted amount of } \\
\text { citrulline by } \mathrm{RSM}(\mu \mathrm{g} / \mathrm{mL})\end{array}$ \\
\hline 1 & $44(1)$ & $7(0)$ & $4(1)$ & $25(0)$ & 0 & 2 \\
\hline 2 & $30(-1)$ & $7(0)$ & $0.1(-1)$ & $25(0)$ & 5 & 3 \\
\hline 3 & $30(-1)$ & $7(0)$ & $2.05(0)$ & $50(1)$ & 8 & 4 \\
\hline 4 & $37(0)$ & $7(0)$ & $2.05(0)$ & $25(0)$ & 18 & 16 \\
\hline 5 & $37(0)$ & $9(1)$ & $4(1)$ & $25(0)$ & 11 & 14 \\
\hline 6 & $37(0)$ & $7(0)$ & $4(1)$ & $0(-1)$ & 30 & 24 \\
\hline 7 & $30(-1)$ & $7(0)$ & $4(1)$ & $25(0)$ & 9 & 11 \\
\hline 8 & $44(1)$ & $7(0)$ & $2.05(0)$ & $50(1)$ & 0 & 0 \\
\hline 9 & $37(0)$ & $5(-1)$ & $2.05(0)$ & $0(-1)$ & 24 & 24 \\
\hline 10 & $37(0)$ & $5(-1)$ & $0.1(-1)$ & $25(0)$ & 10 & 8 \\
\hline 11 & $44(1)$ & $7(0)$ & $2.05(0)$ & $0(-1)$ & 0 & 5 \\
\hline 12 & $44(1)$ & $5(-1)$ & $2.05(0)$ & $25(0)$ & 0 & 1 \\
\hline 13 & $37(0)$ & $7(0)$ & $4(1)$ & $50(1)$ & 16 & 17 \\
\hline 14 & $37(0)$ & $5(-1)$ & $2.05(0)$ & $50(1)$ & 10 & 12 \\
\hline 15 & $30(-1)$ & $7(0)$ & $2.05(0)$ & $0(-1)$ & 5 & 10 \\
\hline 16 & $37(0)$ & $7(0)$ & $0.1(-1)$ & $0(-1)$ & 21 & 19 \\
\hline 17 & $44(1)$ & $9(1)$ & $2.05(0)$ & $25(0)$ & 0 & 0 \\
\hline 18 & $30(-1)$ & $5(-1)$ & $2.05(0)$ & $25(0)$ & 5 & 6 \\
\hline 19 & $30(-1)$ & $9(1)$ & $2.05(0)$ & $25(0)$ & 9 & 8 \\
\hline 20 & $37(0)$ & $5(-1)$ & $4(1)$ & $25(0)$ & 30 & 28 \\
\hline 21 & $37(0)$ & $9(1)$ & $0.1(-1)$ & $25(0)$ & 20 & 22 \\
\hline 22 & $37(0)$ & $9(1)$ & $2.05(0)$ & $50(1)$ & 17 & 17 \\
\hline 23 & $44(1)$ & $7(0)$ & $0.1(-1)$ & $25(0)$ & 0 & 0 \\
\hline 24 & $37(0)$ & $7(0)$ & $2.05(0)$ & $25(0)$ & 15 & 16 \\
\hline 25 & $37(0)$ & $7(0)$ & $2.05(0)$ & $25(0)$ & 14 & 16 \\
\hline 26 & $37(0)$ & $9(1)$ & $2.05(0)$ & $0(-1)$ & 22 & 20 \\
\hline 27 & $37(0)$ & $7(0)$ & $0.1(-1)$ & $50(1)$ & 6 & 11 \\
\hline
\end{tabular}

Conducting 27 experiments, four variables were screened (Table 1) in which the factors of the highest assurance levels were defined into separate levels: temperature $\left(\mathrm{X}_{1}\right), \mathrm{pH}\left(\mathrm{X}_{2}\right)$, glucose concentration $\left(\mathrm{X}_{3}\right), \mathrm{MgCl}_{2}$ concentration $\left(\mathrm{X}_{4}\right)$; testing at three levels: a high level denoted by $(+1)$, medium level denoted by $(0)$, a low level denoted by (-1) (listed in Table 1). Other culture conditions and medium constituents were in consistent with the first culture medium, applied in the activity assay (L-arginine $1.5 \%, \mathrm{NaCl} 0.002 \%, \mathrm{KH}_{2} \mathrm{PO}_{4} 0.075 \%, \mathrm{MnCl}_{2} 0.01 \%, \mathrm{FeSO}_{4}$ $0.0005 \%, \mathrm{CaCO} 30.1 \mathrm{M}$ ).

The equation of the effectors is expressed as follows:

$$
\begin{aligned}
\beta_{0}+\beta_{1} x_{1}+\beta_{2} x_{2} & +\beta_{3} x_{3}+\beta_{4} x_{4}+\beta_{12} x_{1} x_{2}+\beta_{13} x_{1} x_{3} \\
& +\beta_{14} x_{1} x_{4}+\beta_{23} x_{2} x_{3}+\beta_{24} x_{2} x_{4}+\beta_{34} x_{3} x_{4} \\
& +\beta_{11} x_{1}^{2}+\beta_{22} x_{2}^{2}+\beta_{33} x_{3}^{2}+\beta_{44} x_{4}^{2}=y
\end{aligned}
$$

In this equation, "y" is the predicted response, " $\beta_{0}$ " is the model constant;" $x_{1}$ ", " $x_{2}$ ", " $x_{3}$ " and " $x_{4}$ " are the independent variables; " $\beta_{1}$ ", " $\beta_{2}$ ", " $\beta_{3}$ "and " $\beta_{4}$ " are the linear coefficients; " $\beta_{12}$ ", " $\beta_{13}$ ", " $\beta_{14}$ ", " $\beta_{23} "$, " $\beta_{24}$ " and " $\beta_{34}$ " are the cross-product coefficients; and " $\beta_{11}$ ", " $\beta_{22}$ ", " $\beta_{33}$ " and " $\beta_{44}$ " are the quadratic coefficients.

\section{ADI enzyme activity assay}

The ADI enzyme activity was analyzed based on the photometric measurement of the citrulline concentration (which is formed following the L-arginine hydrolysis by ADI enzyme), according to the modified diacetylmonoxime thiosemicarbazide (DMT) method (Ni et al., 2011, Boyde and Rahmatullah, 1980). The applied reagents were prepared as follows: 1) acid-ferric solution: $250 \mathrm{~mL}$ of the concentrated sulfuric acid (95-98\%) was added to $550 \mathrm{~mL}$ of distilled water, following by the addition of
$200 \mathrm{~mL}$ of concentrated phosphoric acid (85\%). Cooling to the room temperature, $\mathrm{FeCl}_{3}(2.50 \mathrm{mg} / \mathrm{L})$ was dissolved in the aforementioned solution. 2) diacetylmonoxime solution: $500 \mathrm{mg}$ of diacetylmonoxime (DAMO, 2, 3 butanedione) was added to 100 $\mathrm{mL}$ of distilled water. 3) chromogenic-reagent: $5 \mathrm{mg}$ of thiosemicarbazide was added to $50 \mathrm{~mL}$ of the "reagent 2", following by the addition of the "reagent 1 " (100 mL). The solution was used in 1 hour of the preparation.

The selected colony (Enterobacter sp.sgnl) was cultured in $20 \mathrm{~mL}$ of the designed culture media. Incubating for 24 hours, 2 $\mathrm{mL}$ of each growth medium was collected and centrifuged to measure the amount of liberated citrulline in the supernatants. For this purpose, $3 \mathrm{~mL}$ of the chromogenic solution (reagent 3) was added to $1 \mathrm{~mL}$ of the supernatant and boiled for $5 \mathrm{~min}$ at $100^{\circ} \mathrm{C}$ banmarry. Cooling to the room temperature, the absorbance was measured at $530 \mathrm{~nm}$. The amount of the citrulline was calculated based on the standard curve of the L-citrulline (measured by the same method) and was correlated to the activity of ADI enzyme (which converts L-arginine to L-citrulline).

\section{Sequence and phylogenetic analyses}

Twenty-four of the arginine deiminase related sequences were retrieved in FASTA format from NCBI database. The sequences were selected based on the isolated species in this research and also those species which were studied by other researchers (Table 2). The selected sequences were aligned using T-Coffee (http://www.ebi.ac.uk/ Tools/msa/tcoffee/) to compare the amino acid sequences among different species (Nezafat et al., 2015). Mega 6 software and Neighborhood Joining method were applied to construct the phylogenetic trees. 
Table 2: The arginine deiminase related sequences retrieved in FASTA format from NCBI database for sequence and phylogenetic analyses.

\begin{tabular}{lcc}
\hline Bacterial species & $\begin{array}{c}\text { Accession } \\
\text { number }\end{array}$ & $\begin{array}{c}\text { Protein } \\
\text { length }\end{array}$ \\
\hline Bacillus cereus AH1273 & 228740297 & 410 \\
Bacillus cytotoxicus NVH 391-98 & 152022936 & 410 \\
Bacillus licheniformis & 765364190 & 411 \\
Bacillus thuringiensis IBL 4222 & 228860522 & 410 \\
Citrobacter amalonaticus & 923246961 & 406 \\
Citrobacter freundii GTC 09629 & 486077046 & 406 \\
Citrobacter youngae ATCC 29220 & 291069141 & 407 \\
Cronobacter sakazakii SP291 & 449099762 & 406 \\
Enterobacter asburiae LF7a & 345091594 & 406 \\
Enterobacter cloacae str. Hanford & 523458876 & 406 \\
Enterococcus faecium TX0082 & 313646064 & 409 \\
Enterobacter lignolyticus SCF1 & 308750386 & 406 \\
Enterococcus faecalis EnGen0310 MMH594 & 802262237 & 408 \\
Erwinia mallotivora & 594397452 & 406 \\
Escherichia coli ATCC 25922 & 674303266 & 406 \\
Halobacterium salinarum & 499206621 & 486 \\
Lactobacillus fermentum & 215271739 & 407 \\
Lactobacillus sakei & 2764611 & 409 \\
Mycoplasma arginini & 761598075 & 410 \\
Mycoplasma arthritidis & 5901880 & 409 \\
Mycoplasma penetrans & 768722109 & 410 \\
Pseudomonas aeruginosa & 674743455 & 418 \\
Pseudomonas plecoglossicida & 154183755 & 417 \\
Pseudomonas putida W619 & 169761387 & 417 \\
\hline & &
\end{tabular}

\section{Statistical analysis}

All experiments were conducted in triplicates, presented by means and standard deviation. Statistical analyses were performed by means of one-way analysis of variance (ANOVA), $(p$-value $<0.05)$ and also based on the Minitab software.

\section{RESULTS AND DISCUSSION}

\section{Isolation of the arginine degrading bacteria}

In order to screen the arginine degrading bacteria, a selective culture medium was designed with arginine as the sole nitrogen source; in which only the arginine degrading bacteria were able to utilize the nitrogen source and grow consequently. Moreover, as ammonium is liberated in the arginine degrading pathways, the primary screening was carried out using phenol red as the $\mathrm{pH}$ indicator (Liu et al., 2008) and colonies with the purple zone around were selected as arginine degrading bacteria.

Considering the arginine rich sources and the suitable conditions for the growth of arginine degrading bacteria, different environmental samples were collected. Some of these bacteria have been mentioned as halophilic, according to other studies (Monstadt and Holldorf, 1991); in this regard, a sample was collected from the beach of Oman Sea (sample F). Since some of the arginine degrading bacteria can tolerate the acidic conditions (Casiano-Colón and Marquis, 1988), some of the samples were collected from acidic environments such as vinegar (sample K).

Through the aforementioned primary screening, 11 strains (A-K) were isolated from different areas of Fars and Boushehr province in Iran, which all had the purple zone around and were selected for further analysis.

\section{Activity determination of arginine degrading enzymes}

These species were further analyzed by Nessler's reagent, in order to quantitatively determine the activity of arginine degrading enzymes, according to the amount of the liberated ammonia. This method has been also applied for the determination of the ammonia concentration as a product of enzymatic degradation by asparaginase (Ghoshoon et al., 2015) and cytosine deaminase (Gholami et al., 2015).

The concentration of the liberated ammonia by test samples is presented in figure 1. One way ANOVA analysis revealed a significant difference between 11 bacterial species ( $\mathrm{p}$ value $=0.046$ ), considering the amount of the produced ammonia. Conducting Dunnett's test, as the post hoc test, the amounts of the produced ammonia by different samples were compared to the sample "C".

It was observed that the amount of the produced ammonia by the sample "I" is significantly higher than sample "C" (p-value $=0.032)$. Among the isolated species, sample "I", which was further identified as Bacillus sp. sgn10, produced the highest amount of ammonia $(0.077 \mathrm{mg} / \mathrm{mL})$ through the degradation of arginine; which can be assigned to the highest amount or activity of arginine degrading enzymes (Fig.1).

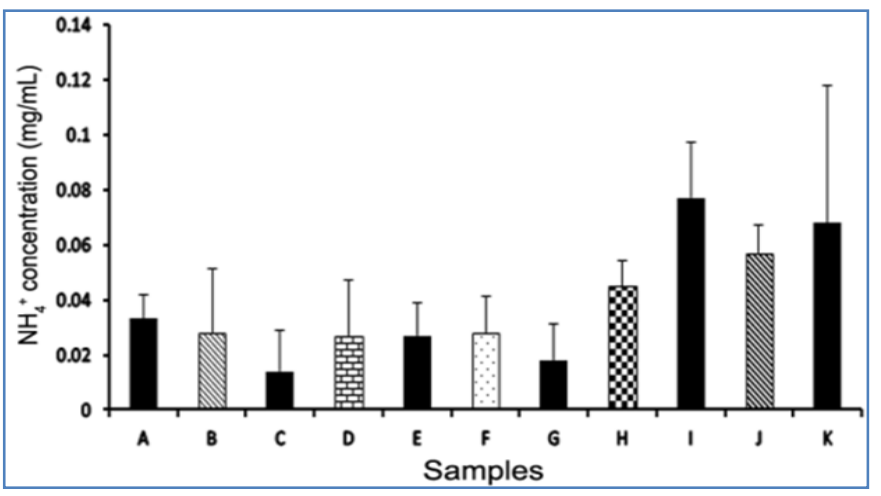

Fig. 1: $\mathrm{NH}_{4}{ }^{+}$concentration $(\mathrm{mg} / \mathrm{mL})$ produced by the isolated bacteria: A. Enterobacter sp. sgn1, B. Cronobacter sp. sgn2, C. Cronobacter sp. sgn3, D. Erwinia sp. sgn4, E. Acinetobacter sp. sgn6, F. Oceanimonas sp. sgn7, G. Enterobacter sp. sgn8, H. Erwinia sp. sgn9, I. Bacillus sp. sgn10, J. Bacillus sp. sgn11, K. Erwinia sp. sgn12. Data are expressed as mean \pm SD of three independent samples. The statistically significant differences in ammonia concentration, compared to the sample "C", are represented by asterisks $(*)$.

\section{Identification of the isolated bacteria by sequence analysis of 16S rRNA gene}

Comparing the sequences of 16s rRNA genes with complete GenBank database (using BLASTN), the isolated samples, represented 99-100\% homology with Enterobacter $s p$. (samples A and G), Cronobacter sp. (samples B and C), Erwinia $s p$. (samples $\mathrm{D}, \mathrm{H}$ and $\mathrm{K}$ ), Acinetobacter $s p$. (sample $\mathrm{E})$, Oceanimonas sp. (sample F) and Bacillus sp. (samples I and J).

The isolated species were supposed to produce arginine degrading enzymes such as arginine deiminase, arginase and arginine decarboxylase. The sequences of 16S rRNA gene were deposited in GenBank under the specific accession numbers (Table 3). 
Table 3: Accession numbers of the 11 environmentally isolated bacteria published in NCBI

\begin{tabular}{|c|c|c|}
\hline Samples & Accession numbers & Bacteria \\
\hline A & JX456240.1 & Enterobacter sp. sgnl \\
\hline B & JX456241.1 & Cronobacter sp. sgn 2 \\
\hline $\mathrm{C}$ & JX456242.1 & Cronobacter sp. sgn 3 \\
\hline $\mathrm{D}$ & JX456243.1 & Erwinia sp. sgn4 \\
\hline $\mathrm{E}$ & JX456244.1 & Acinetobacter sp. sgne \\
\hline $\mathrm{F}$ & JX456245.1 & Oceanimonas sp. sgn 7 \\
\hline G & JX456246.1 & Enterobacter sp. sgn8 \\
\hline $\mathrm{H}$ & JX456247.1 & Erwinia sp. sgn 9 \\
\hline I & JX456248.1 & Bacillus sp. sgn 10 \\
\hline $\mathrm{J}$ & JX456249.1 & Bacillus sp. sgn11 \\
\hline $\mathrm{K}$ & JX456250.1 & Erwinia sp. sgn12 \\
\hline
\end{tabular}

For further study, ADI enzyme was considered (among the arginine degrading enzymes), regarding its advantages over other arginine degrading enzymes like more affinity for arginine compared to arginase, and fewer side effects compared to arginine decarboxylase (Savaraj et al., 2010).

Therefore, among the isolated species, Enterobacter $s p$. sgnl (sample A) was selected for further study, as to the best of our knowledge; this species was not studied as a source of ADI, previously.

\section{Optimization of ADI enzyme production and activity assay}

Using RSM (Box-Behnken design), the effect of four factors (temperature, $\mathrm{pH}$, glucose and $\mathrm{MgCl}_{2}$ concentration) on ADI enzyme activity produced by Enterobacter sp. sgnl was determined. Other researches have reported the effect of various factors, which affected the ADI enzyme in different microorganisms such as: Pseudomonas plecoglossicida (Liu et al., 2008), Euglena gracilis (Park et al., 1984), Halobacterium salinarium (Monstadt and Holldorf, 1991), Pseudomonas putida
(Kakimoto et al., 1971), Lactobacillus plantarum (Arena et al., 1999), Streptococcus faecalis (Simon et al., 1982), Pseudomonas aeruginosa (Baur et al., 1989). Using this method, we could examine the influence of 4 factors at a time with 27 designed experiments. Such a designing also helps us to determine the function of the designed factors' interaction on enzyme production and activity.

The derived regression equation for the optimization of the culture conditions indicated that the ADI activity, which is correlated to the amount of produced citrulline (y), is affected by temperature $\left(x_{1}\right), \mathrm{pH}\left(x_{2}\right)$, the concentration of glucose $\left(x_{3}\right)$ and $\mathrm{Mg}^{+}$ion $\left(x_{4}\right)$. The following second order multinominal equation can display the relation between 4 factors, which were analyzed in this study.

$$
\begin{aligned}
0.0157-0.0034 x_{1}- & 0.0000 x_{2}+0.0028 x_{3}-0.0037 x_{4}-0.0010 x_{1} x_{2} \\
& -0.0010 x_{1} x_{3}-0.0007 x_{1} x_{4}-0.0072 x_{2} x_{3} \\
& +0.0022 x_{2} x_{4}+0.0002 x_{3} x_{4}-0.0135 x_{1}^{2}+0.0012 x_{2}^{2} \\
& +0.0012 x_{3}^{2}+0.0013 x_{4}^{2}=\mathrm{y}
\end{aligned}
$$

The effects of the variables are shown in table 1 in which the observed responses are compared with the predicted responses which were obtained from Box-Behnken designed experiments. Table 4 represents the interaction between the test variables, $p$ values and confidence level (\%). According to the calculated $p$ values, it is observed that out of the 4 studied variables, three variables (temperature, glucose and $\mathrm{Mg}^{+}$concentration) had a significant effect on the ADI enzyme production and activity ( $p$ value $<0.05$, significant at $5 \%$ level). Although the $\mathrm{pH}$ value did not significantly affect the ADI enzyme production and activity,

\begin{tabular}{|c|c|c|c|c|c|}
\hline Variable & Coefficient & SE Coefficient & T statistic & P value & Confidence level (\%) \\
\hline Constant & 0.015667 & 0.002370 & 6.610 & 0.000 & 100 \\
\hline Temperature & -0.003417 & 0.001185 & -2.883 & 0.014 & 98.6 \\
\hline $\mathrm{pH}$ & -0.000000 & 0.001185 & -0.000 & 1.000 & 0 \\
\hline Glucose & 0.002833 & 0.001185 & 2.391 & 0.034 & 96.6 \\
\hline $\mathrm{Mg}^{+}$ & -0.003750 & 0.001185 & -3.164 & 0.008 & 99.2 \\
\hline Temperature $*$ Temperature & -0.013458 & 0.001778 & -7.571 & 0.000 & 100 \\
\hline $\mathrm{pH} * \mathrm{pH}$ & 0.001167 & 0.001778 & 0.656 & 0.524 & 47.6 \\
\hline Glucose * Glucose & 0.001167 & 0.001778 & 0.656 & 0.524 & 47.6 \\
\hline $\mathrm{Mg}^{+*} \mathrm{Mg}^{+}$ & 0.001292 & 0.001778 & 0.727 & 0.481 & 51.9 \\
\hline Temperature * $\mathrm{pH}$ & -0.001000 & 0.002053 & -0.487 & 0.635 & 36.5 \\
\hline Temperature * Glucose & -0.001000 & 0.002053 & -0.487 & 0.635 & 36.5 \\
\hline Temperature $* \mathrm{Mg}^{+}$ & -0.000750 & 0.002053 & -0.365 & 0.721 & 27.9 \\
\hline $\mathrm{pH} *$ Glucose & -0.007250 & 0.002053 & -3.532 & 0.004 & 99.6 \\
\hline $\mathrm{pH} * \mathrm{Mg}^{+}$ & 0.002250 & 0.002053 & 1.096 & 0.295 & 70.5 \\
\hline Glucose ${ }^{*} \mathrm{Mg}^{+}$ & 0.000250 & 0.002053 & 0.122 & 0.905 & 9.5 \\
\hline
\end{tabular}
the observed values revealed that its interaction with glucose concentration could have significant effect (Fig. 2).

Table 4: The results of Regression Analysis of Box-Behnken Design for ADI Production by Enterobacter sp. sgn1. 

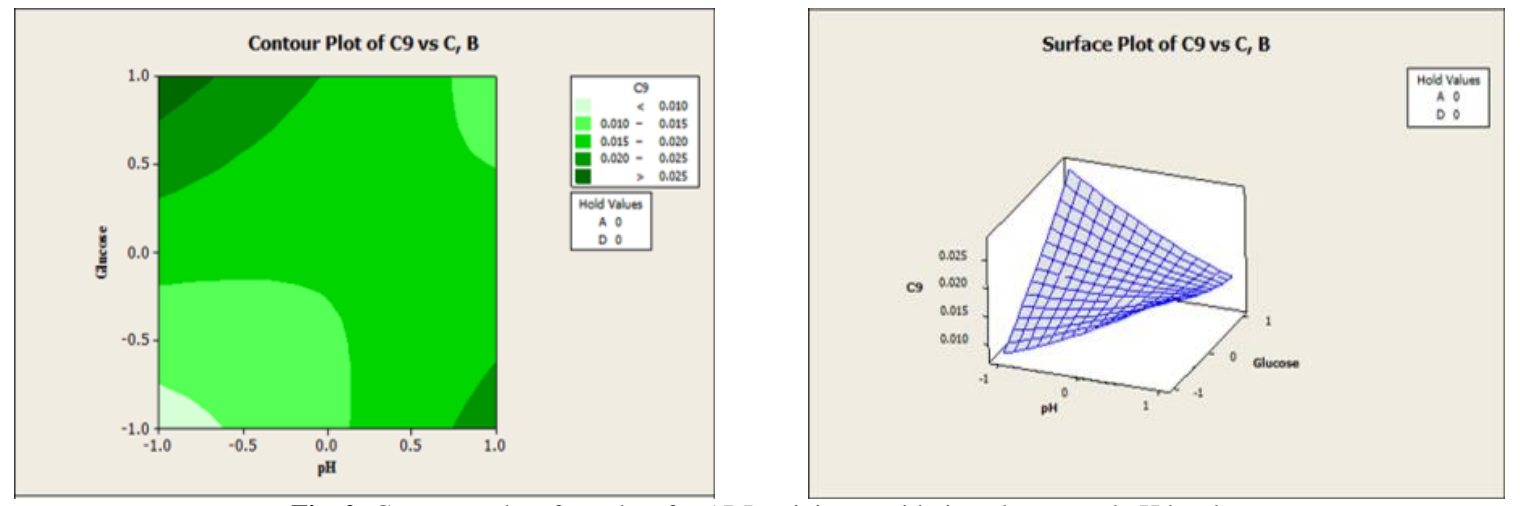

Fig. 2: Counter and surface plots for ADI activity considering glucose and $\mathrm{pH}$ level

The amount of the produced citrulline, which is correlated to the ADI enzyme production and activity, varied from $0-30 \mu \mathrm{g} / \mathrm{mL}$ in the lowest and the highest amount in the designed experiments. The highest ADI enzyme production and activity was observed in the designed conditions of experiments 6 and 20. So we can conclude that the best culture condition for ADI production obtains at $37^{\circ} \mathrm{C}$ with the glucose concentration of $4 \%, \mathrm{pH}$ of 5-7 and $\mathrm{Mg}^{+}$concentration of $0-25 \mathrm{M}$, while other factors such as $\mathrm{L}$ arginine $1.5 \%, \mathrm{NaCl} 0.002 \%, \mathrm{KH}_{2} \mathrm{PO}_{4} 0.075 \%, \mathrm{MnCl}_{2} 0.01 \%$, $\mathrm{FeSO}_{4} 0.0005 \%, \mathrm{CaCO}_{3} 0.1 \mathrm{M}$ are constant in all designed experiments. $\mathrm{R}^{2}$ value (the coefficient of multiple determinations) which is always between 0 and 1 , represents the adequacy of the designed model: the closer the $\mathrm{R}^{2}$ value to 1 , the stronger the predicted response. In this study, the $\mathrm{R}^{2}$ value was 0.9082 which suggested that the model can explain up to $90.82 \%$ of data variation. The observed correlation between the predicted and the experimentally obtained results also proves that the designed model has been appropriate to analyze the obtained responses.

\section{Verification of the model}

In order to verify the model which was designed for the optimization of ADI production, an experiment was designed for the analyzed parameters (using Minitab software and according to our results); temperature of about $33^{\circ} \mathrm{C}$, glucose concentration of $4 \%, \mathrm{pH}=5$ and $\mathrm{Mg}^{+}$concentration of $0 \mathrm{M}$. The amount of the produced citrulline was predicted to be $35 \mu \mathrm{g} / \mathrm{mL}$ in the designed condition which experimentally determined to be $31 \mu \mathrm{g} / \mathrm{mL}$. This result revealed $88.6 \%$ accuracy and is an evidence on the validity of the designed model under the investigated circumstances, which indicates the reliability of the model for the maximal ADI production and activity by Enterobacter sp. sgnl.

\section{Sequence and phylogenetic analyses of arginine deiminase sequences}

Currently, the pegylated form of arginine deaminase (from Mycoplasma arginini) is investigating in clinical trials for the treatment of arginine auxotrophic tumors (Ni et al., 2008). In this study, the ADI sequences of the isolated species were compared to the sequence of Mycoplasma arginini to find other ADI producers with similar sequences. Conserved regions were observed in the multiple sequence alignment in $1,13,17,20,25$, $40,55,161,164,166,167,175,181,186,189,225,226,227,228$, 240, 279, 280, 281, 282, 283,291, 366, 372, 403, 406, 408, 412, 413, 416 and 419 amino acid residues (Fig. 3). Based on the phylogenetic study, three major clusters were observed in the constructed phylogenetic tree (Fig. 4). Among the isolated species in this study, Bacillus species (belong to the second cluster) are very close to Mycoplasma species (sharing 94\% of homology). These species are also close to Lactobacillus species and Enterococcus species. According to their similarity with Mycoplasma species, these species might be considered as a source of ADI, conducting more studies. Erwinia sp., Cronobacter $s p$. and Enterobacter sp., which belong to the first cluster, are very close to each other and share $99 \%$ of homology with Pseudomonas sp. It was observed that Halobacterium salinarum was categorized as a distinct cluster. This species is a member of Archaebacterial Kingdom and contains the ADI gene which is completely apart from other species.

\section{CONCLUSION}

In order to find novel ADI sources, in the present study, a convenient method was established, using a selective medium, to isolate arginine degrading bacteria from local samples. They were further identified as Enterobacter sp., Cronobacter sp., Erwinia sp., Acinetobacter sp., Oceanimonas sp. and Bacillus sp. Moreover, four factors which could affect the ADI production and activity, produced by Enterobacter sp. sgnl as a source of this enzyme, were studied for the first time (using RSM). It was observed that temperature, glucose concentration, $\mathrm{Mg}^{+}$ concentration and the interaction of $\mathrm{pH}$ and glucose concentration had a significant effect on the production and activity of ADI enzyme. Comparing the ADI sequences of the isolated species with Mycoplasma arginini, it was observed that Bacillus species are very close to Mycoplasma species. Conducting more studies about the isolated species, might result in the possible application of them as potential sources for ADI enzyme. 


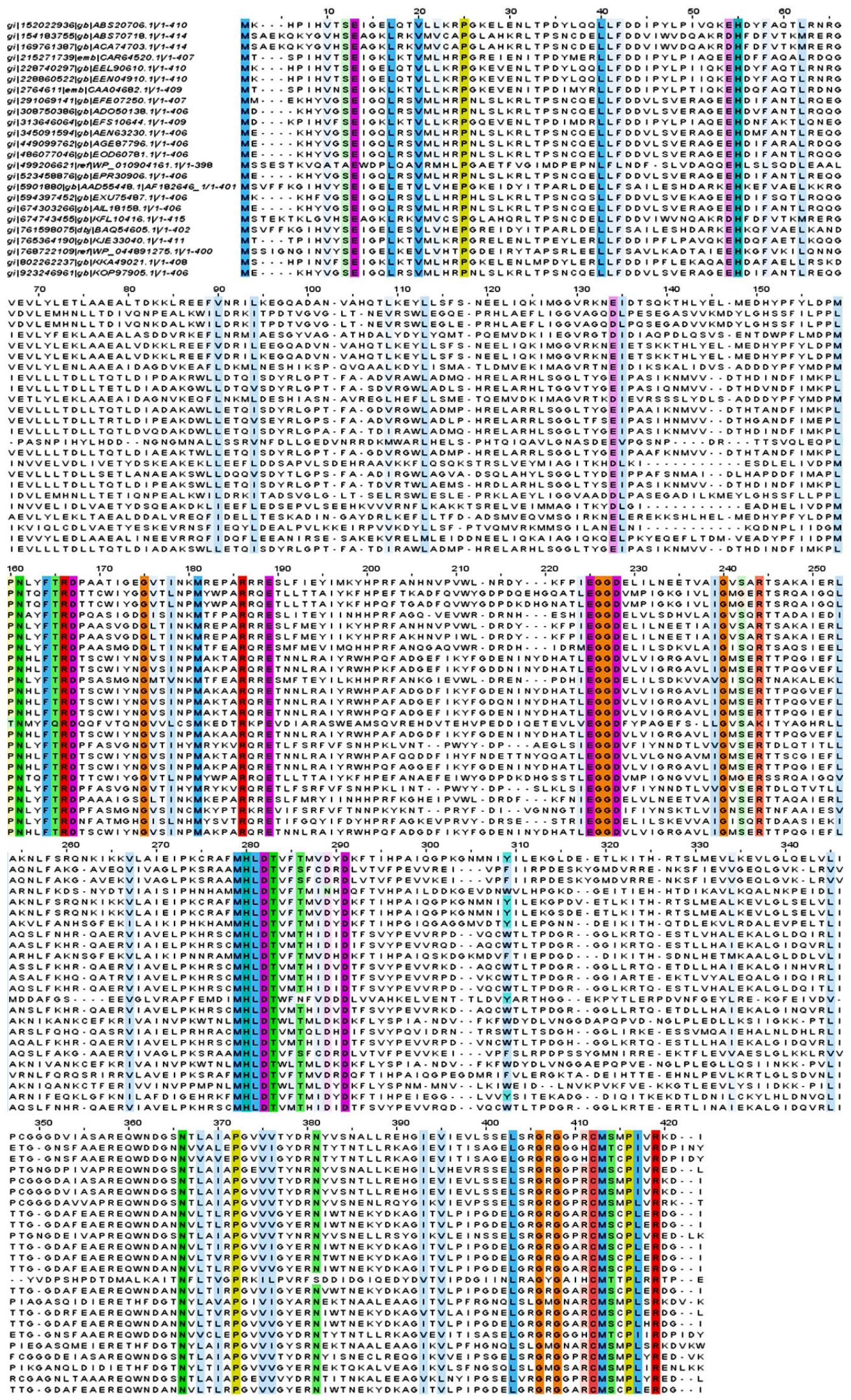

Fig. 3: Multiple sequence alignment of ADI genes (colored based on clustalx matrix and 50\% conservation). 


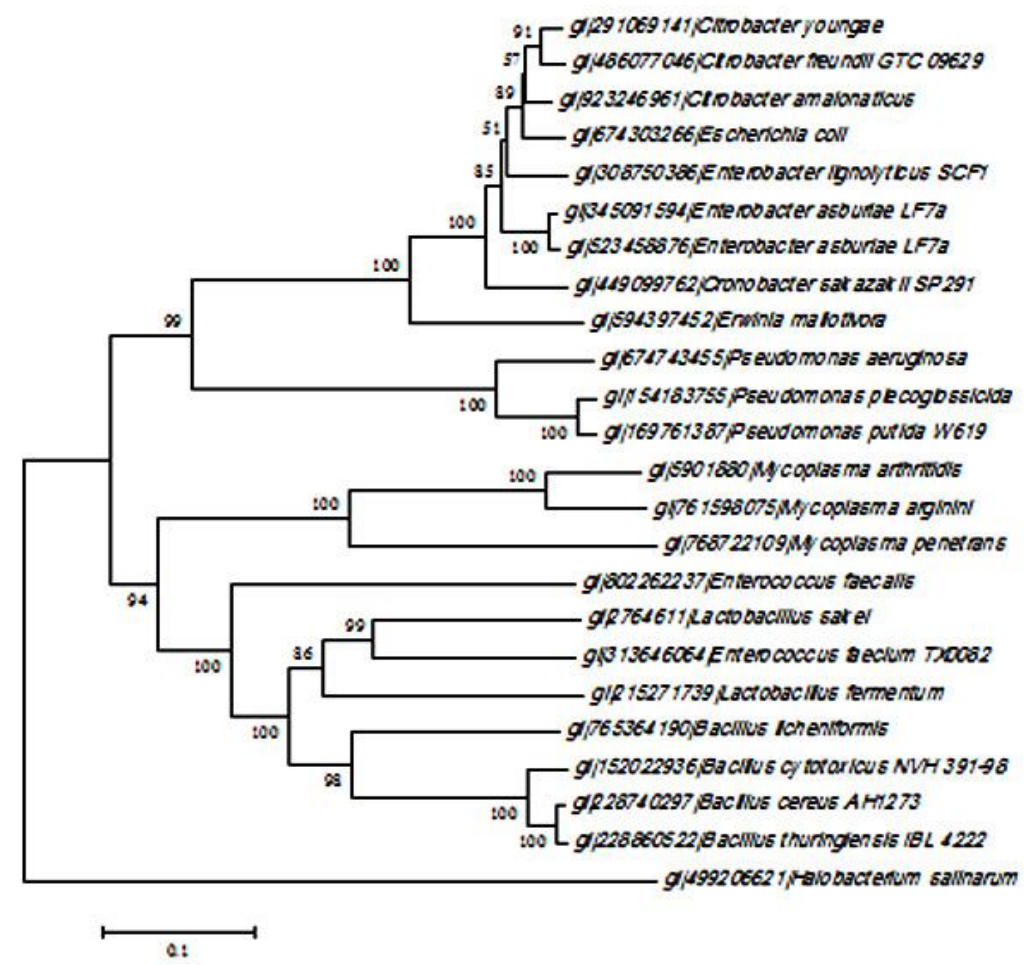

Fig. 4: Phylogenetic trees constructed by Neighbor-Joining method (by means of MEGA 6) based on ADI genes from different species. Bootstrap values and genetic distance are presented.

\section{Financial support and sponsorship: Nil.}

Conflicts of interest: There are no conflicts of interest.

\section{REFERENCES}

Arena M, Saguir F, De Nadra M M. Arginine dihydrolase pathway in Lactobacillus plantarum from orange. Int J Food Microbiol, 1999; 47(3):203-209.

Baur H, Luethi E, Stalon V, Mercenier A, Haas D. Sequence analysis and expression of the arginine-deiminase and carbamate-kinase genes of Pseudomonas aeruginosa. Eur J Biochemi, 1989; 179(1):53-60.

Boyde T, Rahmatullah M. Optimization of conditions for the colorimetric determination of citrulline, using diacetyl monoxime. Anal Biochem, 1980; 107(2):424-431.

Casiano-Colón A, Marquis R E. Role of the arginine deiminase system in protecting oral bacteria and an enzymatic basis for acid tolerance. Appl. Environ. Microb, 1988; 54(6):1318-1324.

Ensor C M, Holtsberg F W, Bomalaski J S, Clark M A. Pegylated arginine deiminase (ADI-SS PEG20, $000 \mathrm{mw}$ ) inhibits human melanomas and hepatocellular carcinomas in vitro and in vivo. Cancer Res, 2002; 62(19):5443-5450.

Feun L, Savaraj N. Pegylated arginine deiminase: a novel anticancer enzyme agent. Expert Opin Invest Drugs, 2006; 15(7):815-822.

Feun L, You M, Wu C, Kuo M, Wangpaichitr M, Spector S, Savaraj N. Arginine deprivation as a targeted therapy for cancer. Curr Pharm Des, 2008; 14(11):1049-1057.

Ghasemi Y, Ebrahiminezhad A, Rasoul-Amini S, Zarrini G, Ghoshoon M B, Raee M J, Morowvat M H, Kafilzadeh F, Kazemi A. An optimized medium for screening of L-asparaginase production by Escherichia coli. Am J Biochem Biotechnol, 2008; 4(4):422-424.

Gholami A, Shahin S, Mohkam M, Nezafat N, Ghasemi Y. Cloning, characterization and bioinformatics analysis of novel cytosine deaminase from Escherichia coli AGH09. Int. J. Pept Res Ther, 2015; 21(3):365-374.
Ghoshoon M B, Berenjian A, Hemmati S, Dabbagh F, Karimi Z, Negahdaripour M, Ghasemi Y. Extracellular production of recombinant 1-Asparaginase II in Escherichia coli: medium optimization using response surface methodology. Int J Pept Res Ther, 2015; 21(4):487-495.

Izzo F, Marra P, Beneduce G, Castello G, Vallone P, De Rosa V, Cremona F, Ensor C M, Holtsberg F W, Bomalaski J S. Pegylated arginine deiminase treatment of patients with unresectable hepatocellular carcinoma: results from phase I/II studies. JClinOncol, 2004; 22(10):1815-1822.

Kakimoto T, Shibatani T, Nishimura N, Chibata I. Enzymatic production of L-citrulline by Pseudomonas putida. Appl Microb, 1971; 22(6):992-999.

Kazemi A, Rasoul-Amini S, Shahbazi M, Safari A, Ghasemi Y Isolation, identification, and media optimization of high-level cellulase production by Bacillus sp. BCCS A3, in a fermentation system using response surface methodology. Prep Biochem Biotechnol, 2014; 44(2):107-118.

Kim J, Hur H J, Lee K, Lee H. Anti-inflammatory effects of recombinant arginine deiminase originating from Lactococcus lactis ssp. lactis ATCC 7962. JMicrobiol Biotechnol, 2007; 17(9):1491.

Knodler L A, Sekyere E O, Stewart T S, Schofield P J, Edwards $\mathrm{M}$ R. Cloning and expression of a prokaryotic enzyme, arginine deiminase, from a primitive eukaryote Giardia intestinalis. J Biol Chem, 1998; 273(8):4470-4477.

Kuo M T, Savaraj NFeun L G. Targeted cellular metabolism for cancer chemotherapy with recombinant arginine-degrading enzymes. Oncotarget, 2010; 1(4):246.

Liu Y-M, Sun Z-H, Ni Y, Zheng P, Liu Y-P, Meng F-J. Isolation and identification of an arginine deiminase producing strain Pseudomonas plecoglossicida CGMCC2039. World J Microbiol Biotechnol, 2008; 24(10):2213-2219.

Mercenier A, Simon J-P, Vander Wauven C, Haas D, Stalon V. Regulation of enzyme synthesis in the arginine deiminase pathway of Pseudomonas aeruginosa. JBacteriol, 1980; 144(1):159-163.

Monstadt G M, Holldorf A. Arginine deiminase from Halobacterium salinarium. Purification and properties. Biochem J, 1991; 273:739-745. 
Nezafat N, Negahdaripour M, Gholami A, Ghasemi Y. Computational analysis of collagenase from different Vibrio, Clostridium and Bacillus strains to find new enzyme sources. Trends Pharm Sci, 2015; 1(4):213-222.

Ni Y, Li Z, Sun Z, Zheng P, Liu Y, Zhu L, Schwaneberg U. Expression of arginine deiminase from Pseudomonas plecoglossicida CGMCC2039 in Escherichia coli and its anti-tumor activity. CurrMicrobiol, 2009; 58(6):593-598.

Ni Y, Liu Y, Schwaneberg U, Zhu L, Li N, Li L, Sun Z. Rapid evolution of arginine deiminase for improved anti-tumor activity. ApplMicrobiol Biotechnol, 2011; 90(1):193-201.

Ni Y, Schwaneberg U, Sun Z-H. Arginine deiminase, a potential anti-tumor drug. Cancer Lett, 2008; 261(1):1-11.

Niven Jr C, Smiley K, Sherman J. The hydrolysis of arginine by streptococci. J Bacteriol, 1942; 43(6):651.

Park B-S, Hirotani A, Nakano Y, Kitaoka S. Purification and some properties of arginine deiminase in Euglena gracilis Z. Agric. Biol Chem, 1984; 48(2):483-489.

Piatkowska-Jakubas B, Krawczyk-Kuliś M, Giebel S, Adamczyk-Cioch M, Czyz A, Lech M E, Paluszewska M, Pałynyczko G, Piszcz J, Hołowiecki J. Use of L-asparaginase in acute lymphoblastic leukemia: recommendations of the Polish Adult Leukemia Group. Pol Arch Med Wewn, 2008; 118(11):664-669.

Savaraj N, You M, Wu C, Wangpaichitr M, Kuo M, Feun L. Arginine deprivation, autophagy, apoptosis (AAA) for the treatment of melanoma. Curr Mol Med, 2010; 10(4):405.

Shen L-J, Beloussow K, Shen W-C. Modulation of arginine metabolic pathways as the potential anti-tumor mechanism of recombinant arginine deiminase. Cancer Lett, 2006; 231(1):30-35.

Simon J, Wargnies B, Stalon V. Control of enzyme synthesis in the arginine deiminase pathway of Streptococcus faecalis. J Bacteriol, 1982; 150(3):1085-1090.
Singh Y, Gundampati R K, Jagannadham M V, Srivastava S. Extracellular L-asparaginase from a protease-deficient Bacillus aryabhattai ITBHU02: purification, biochemical characterization, and evaluation of antineoplastic activity in vitro. Appl Biochem Biotechnol, 2013; 171(7):1759-1774.

Stone E M, Glazer E S, Chantranupong L, Cherukuri P, Breece R M, Tierney D L, Curley S A, Iverson B L, Georgiou G. Replacing $\mathrm{Mn}^{2+}$ with $\mathrm{Co}^{2+}$ in human arginase I enhances cytotoxicity toward 1-arginine auxotrophic cancer cell lines. ACS Chem Biol, 2010; 5(3):333-342.

Zúñiga M, Pérez G, González-Candelas F. Evolution of arginine deiminase (ADI) pathway genes. Mol Phylogenet Evol, 2002; 25(3):429444.

\section{How to cite this article:}

Ebrahimi N, Gharibi S, Ghoshoon MB, Karimi Z, Gholami A, Nezafat N, Mohkam M, Ghasemi Y. Selective Isolation and Identification of Arginine Degrading Bacteria; the Optimized Arginine Deaminase Production by Enterobacter sp. sgnl as a New Source of This Potentially Anti-Tumor Enzyme. J App Pharm Sci, 2016; 6 (09): 093-101. 